\title{
Factors That Influence the Adoption of Computer Assisted Audit Techniques (CAATs) by External Auditors in Yemen
}

\author{
AL Barak Khalil (Corresponding author) \\ Accounting Department, ISCAE, University of Manouba, Tunisia \\ E-mail: Albrak470@gmail.com
}

\begin{abstract}
Nafti Olfa
Associate professor, Department of Accounting and Finance, ISCAE

University of Manouba, Tunisia

E-mail: olfa.nafti@iscae.rnu.tn
\end{abstract}

Received: March 17, 2020

doi:10.5296/ijafr.v10i2.16692
Accepted: April 8, 2020

Published: April 12, 2020

URL: https://doi.org/10.5296/ijafr.v10i2.16692

\begin{abstract}
External auditors face new challenges in keeping pace with technological development in the accounting profession, which is how to audits outputs of advanced electronic accounting systems. As a result, several electronic systems and applications have emerged to assist the external auditors in their tasks, which called Computer -Assisted Audit Techniques (CAATs). The main objective of this study to examine the factors influencing of adoption of CAATs in the external audit process in Yemen, using Structural Equation Modeling (SEM). The Unified Theory of Acceptance and Use of Technology (UTAUT) was utilized as a theoretical basis in this study. A quantitative approach was carried out by a questionnaire completed by 312 participants. The results mainly showed that the behavioral intention to adopt CAATs is significantly and positively influenced by the performance expectancy, social influence and facilitating conditions, but it was not influenced by the effort expectancy. Besides, this is the first study in Yemen about the adoption of CAATs.
\end{abstract}

Keywords: External audit, Computer-Assisted Audit Techniques (CAATs), Unified Theory of Acceptance and Use of Technology (UTAUT), Structural Equation Modeling (SEM) 


\section{Introduction}

Information Technology (IT) is one of the most crucial events that affected the auditing profession in the modern era (Rosli et al., 2012 and Mohammed et al., 2017). These events included more advanced automated technologies, growing electronic transactions for both customers and suppliers, and rapid expansion of the data available (AICPA, 2015). Besides, IT is one of the most important environmental variables, which affected the profession of accounting. These changes also led to the disappearance or semi-disappearance of the traditional manual accounting systems. Furthermore, paper evidence disappeared and was replaced by electronic evidence. However, IT provides tools for companies to face these changes (Mustapha \& Lai, 2017).

The volume data of companies and citizens grew during the period from 2005 to 2020 with an expected average of 300 to 5,300 GB / human (Pedrosa et al., 2019). In addition to that, the rapid advancement in information technology has led to a revolution in the auditing methods (Lin \& Wang, 2011).

The traditional audit requires enormous human resources and more time to implement. Besides, auditors cannot obtain sufficient and appropriate evidence to perform extensive audit activities and maintain audit quality (Wu, 2015). Therefore, the auditors should learn all the new in audit to meet the requirements of the standard of scientific and practical qualification. As well as follow up the International Standards on Auditing (ISA) about IT (Vasile-Daniel, 2010).

As a result, several electronic systems and applications have emerged to assist in the audit of computer systems, called Computer-Assisted Audit Techniques (CAATs). The CAATs are electronic techniques as electronic audit working papers software, fraud detection software, generalized audit software, and continuous monitoring software (Mahzan \& Lymer, 2014). Moreover, CAATs are a logical technological method to achieve IT audits related to computer usage. In this context, the auditor should have a better understanding of the nature of the electronic software, and the functions that can be performed through it.

IT helps the external auditors to make their works more efficient and effective. It also decreases the time of substantive tests during the audit process (Mustapha \& Lai, 2017). Because of this, to meet the challenges of extremely advances in client technology, International Standards on Auditing (ISA) had provided recommendations and guidance for the adoption of CAATs (AICPA 2001, 2002a, 2002b, 2002c, 2006; PCAOB, 2007, 2010b; IFAC, 2009). Besides, the auditors use the CAATs to extract and analyze the client data (Shamsuddin et al., 2015). The Sarbanes-Oxley Act indicated the important role of information technology in maintaining internal control. Thus, the auditors must know the new technology to deal with the new challenges in the technology environment (Lin \& Wang, 2011).

The CAATs include five categories: test data technique, integrated testing technique, parallel simulation technique, embedded audit and generalized audit software (Braun \& Davis, 2003). Besides, the auditor requires understanding how the system works and how the internal 
control works inside the system. Previous studies indicated that technology cannot achieve its benefits if it is not used continuously.

On the other hand, some previous studies had developed several theoretical models to predict the acceptance and use of technology (Davis, 1986; Davis et al., 1989; Venkatesh and Davis, 2000; Venkatesh et al., 2003). On another hand, some previous studies utilized these theoretical models to predict users' acceptance and use of CAATs in the audit process.

Additionally, the UTAUT was utilized as a theoretical basis to adopt and use CAATs in some previous studies. For instance, (Bierstaker et al., 2014; Curtis \& Payne, 2014; Mahzan \& Lymer, 2014; Ebimobowei et al., 2013; Shamsuddin et al., 2015; Mansour, 2016; Kim et al., 2016; Zainol et al., 2017; Al-Hiyari et al., 2019 and Pedrosa et al., 2019). Therefore, it is important to know the factors that influence the auditor's decision to adopt CAATs, which will affect both the work and audit practice, which will affect both the work and audit practice (Curtis \& Payne, 2008).

Meanwhile, some of the previous studies indicated that the adoption and usage of CAATs in the audit process require more research (Debreceny et al., 2005; Janvrin et al., 2008; Bierstaker et al., 2014; Byrnes et al., 2015). Thus, there is still a lack of computerized audit in developing countries (Oni, 2015). Moreover, previous studies in Yemen did not address the factors that influence CAATs adoption among external auditors. Therefore, the problem of this study represented in the following question:

What factors influence the adoption of Computer-Assisted Audit Techniques (CAATs) in the audit process from the perspectives of external auditors in Yemen?

The remaining sections of this paper are structured as follows: The second section offers the literature review and hypotheses development. The third section proposes the research model. The fourth section presents the methodology description. Section fifth presents the findings of the study. Section sixth discusses the findings. The last section presents the conclusion, contribution, theoretical implications, limitations, and future researches.

\section{Literature Review and Hypothesis Development}

\subsection{Literature Review}

Several studies explored the intention to adopt CAATs in different countries (Janvrin et al. 2008; Ebimobowei et al., 2013; Bierstaker et al. 2014; Curtis \& Payne, 2014; Pedrosa, 2015; Mansour, 2016; Mohammad et al., 2017; Zainol et al., 2017; Al-Hiyari et al., 2019; Pedrosa et al., 2019).

(Janvrin et al., 2008) examined auditors' acceptance of CAATs by external auditors in Big4, national, regional, and local firms in the U.S. Their results found that the performance expectancy and facilitating conditions increased the likelihood towards that auditor to use CAATs.

Similarly, (Ebimobowei et al., 2013) examined the factors that influence the CAATs in audit practice in Nigeria by using the UTAUT. Their results revealed that the performance 
expectancy, effort expectancy, facilitating conditions and social influence were positively associated with CAATs usage by accounting firms.

In a study conducted by (Mansour, 2016), which examined the factors affecting the CAATs among Jordanian statutory auditors. The findings found that the performance expectancy and facilitating conditions were significant, but the social influence and effort expectancy were insignificant.

(Zainol et al., 2017) examined factors that affecting the SMPs' behavioral intention of CAATs adoption. The results indicated that the performance expectancy, social influence and facilitating condition have a positive impact on behavioral intention towards CAATs adoption, but the effort expectancy has an insignificant impact on behavioral intention towards the CAATs adoption.

(Al-Hiyari et al., 2019) adopted the UTAUT to examine the determinants of the intention of internal auditors to adopt CAATs in Jordan. They found that the performance expectancy and facilitating conditions have a significant effect on the decision of internal auditors' intention to adopt CAATs.

(Pedrosa et al., 2019) examined the determinants adoption of computer-assisted auditing tools in Portugal. They found evidence that the perceived usefulness, effort expectancy, facilitating conditions, and the number of auditors are the most likely drivers of the adoption and use of CAATs.

\subsection{Hypotheses Development}

\subsubsection{Performance Expectancy and Behavioral Intention}

Performance Expectancy (PE) refers to the degree to which an individual believes that utilizing a new tool will assist him or her to achieve the gain in job performance (Venkatesh et al., 2003). The UTAUT suggests that the performance expectancy linked to perceived ease of use and it has a direct positive impact on behavioral intention (Venkatesh et al., 2003). For example, auditors may believe that the use of CAATs will help them to decrease the time required of tests and improve audit efficiency (Janvrin et al., 2008).

In general, auditors seem to be more motivated to use and adopt new technology, if they realize that this technology is more profitable and useful in their daily lives (Davis et al., 1989 and Venkatesh et al., 2003). The performance expectancy influences on the likelihood auditors adopt the CAATs in audit process (Janvrin et al., 2008; Bierstaker et al., 2014; Ebimobowei et al., 2013; Mansour,2016; Mohammad et al., 2017; Zainol et al., 2017; Al-Hiyari et al., 2019 and Pedrosa et al., 2019). Therefore, this study assumes the following hypothesis:

H1 Performance expectancy has a positive impact on the external auditors' behavioral intention to adopt CAATs in Yemen.

\subsubsection{Effort Expectancy and Behavioral Intention}

Effort Expectancy (EE) refers to "the degree of ease associated with the use of a system" 


\section{Macrothink}

International Journal of Accounting and Financial Reporting

ISSN 2162-3082

2020, Vol. 10, No. 2

(Venkatesh et al., 2003). (Gonzalez et al., 2012) found that the internal auditors' perception of effort expectancy was a significant predictor of their intentions to use continuous auditing. (Ahmad et al., 2013) (Ahmad et al., 2013) used the UTAUT to examine the factors that affect the adoption of e-government services in Pakistan. Their findings demonstrated that the effort expectancy has a positive impact on the adoption of e-government services in Pakistan.

(Venkatesh et al., 2003) confirmed that indicated the effort expectancy factor has a significant affecting on the behavioral intention towards the adoption of technology. According to (Venkatesh et al., 2003) the individual acceptance of new technology depends on its perceived usefulness and perceived ease. The CAAT's ease of use depends on the external auditor IT training (Janvrin et al., 2008). Thus, the training programs have the potential to increase confidence in the CAATs.

(Ebimobowei et al., 2013; Mohammad et al., 2017 and Pedrosa et al., 2019) found that the effort expectancy has a positive impact on the behavioral intention of external auditors to adopt CAATs. In contrast, (Janvrin et al, 2008; Mahzan \& Lymer, 2013; Bierstaker et al, 2014; Mansour, 2016; Zainol et al, 2017; Al-Hiyari et al., 2019) found that the effort expectancy has an insignificant impact on the behavioral intention of external auditors towards the adoption of CAATs. Thus, this study hypothesizes that:

H2 Effort expectancy has a positive impact on the external auditors' behavioral intentions to adopt CAATs in Yemen.

\subsubsection{Social Influence and Behavioral Intention}

Social influence (SI) is characterized as the extent to which an individual perceives that the crucial others believe he or she should apply the new technology (Venkatesh et al., 2003).

(Venkatesh et al., 2003) found that social influence has an important influence on the user's behavioral intention to adopt the new technology.

Previous researches for instance, (Ebimobowei et al., 2013; Shamsuddin et al., 2016; Mohammad et al., 2017 and Zainol et al., 2017) found that social influence has a significant influence on the behavioral intention towards CAATs adoption. In contrast, (Janvrin et al, 2009; Mahzan \& Lymer, 2014; Bierstaker et al., 2014; Mansour, 2016; Al-Hiyari et al., 2019; Pedrosa et al., 2019) found that the social influence has an insignificant affecting on the behavioral intention towards CAATs adoption. In our expectation in this paper is that social influence will significantly influence behavioral intention towards CAATs adoption. Thus, this study hypothesizes that:

H3 Social Influence has a positive impact on the external auditors' behavioural intentions to adopt CAATs in Yemen.

\subsubsection{Facilitating Conditions and Behavioral Intention}

Facilitating conditions (FC) are defined as "the degree to which an individual believes that an organizational and technical infrastructure exists to support the use of the new system" (Venkatesh et al., 2003). (Janvrin et al., 2008) indicated that the facilitating conditions could 


\section{Ml Macrothink}

International Journal of Accounting and Financial Reporting

ISSN 2162-3082

2020, Vol. 10, No. 2

increase the probability that auditors would use CAATs. Likewise, (Sin Tan, Chong, \& Lin, 2013) examined the factors affecting the intention to use internet marketing in Malaysia and South Korea. They utilized the UTAUT to examine that factors impact on the intention to use internet marketing. Their results demonstrated that facilitating conditions were a significant impact on the intention to use internet marketing.

(Ahmad et al., 2013) studied user's adoption of e-government services in Pakistan. Their results indicated that the facilitating conditions affect the user's adoption of e-government services in Pakistan. (Tumi, 2013) investigated the reasons why auditors in Libya may not make use of the CAATs or continuous auditing (CA), using UTAUT. The results demonstrated that the lack of facilitating conditions to use CAATs.

(Janvrin et al., 2008; Bierstaker et al, 2014; Ebimobowei et al., 2013; Mahzan \& Lymer, 2013; Mansour, 2016; Zainol et al., 2017; Al-Hiyari et al., 2019) found that the facilitating conditions influence the likelihood that auditors will use the CAATs. Therefore, this study assumes the following hypothesis:

H4 Facilitating conditions have a positive impact on the external auditors' behavioral intentions to adopt CAATs in Yemen.

\section{Research Model}

This paper based on the theoretical basis of the technology adoption model that is known as the UTAUT. The UTAUT assumes that four constructs act as determinants of behavioral intentions to adopt CAATs. These four constructs are represented in the performance expectancy, effort expectancy, social influence and facilitating conditions. Facilitating conditions and behavioral intention are direct determinants of behavior usage. Furthermore, gender, age, experience, and voluntary are moderate variables between constructs of behavioral intentions and behavior usage (Venkatesh et al., 2003).

The UTAUT is a technology acceptance model formulated by (Venkatesh et al., 2003). This model was developed from eight theories to explain technology acceptance: Theory of Reasoned Action (TRA), Technology of Acceptance Model (TAM), Motivational Model (MM), Theory of Planned Behavior (TPB), Model of Personal Computer Utilization (MPCU), a combined Theory of Planned Behavior and Technology Acceptance Model (TAM and TPB), Innovation Diffusion Theory (IDF), and Social Cognitive Theory (SCT). (Venkatesh et al., 2003) found that the UTAUT explains up to $70 \%$ of the variance in intention to use the new system, superior to all of the specific models listed above. Figure 1 shows the UTAUT model and Figure 2 shows the model of study. 




Figure 1. UTAUT model

Source: Venkatesh et al., 2003

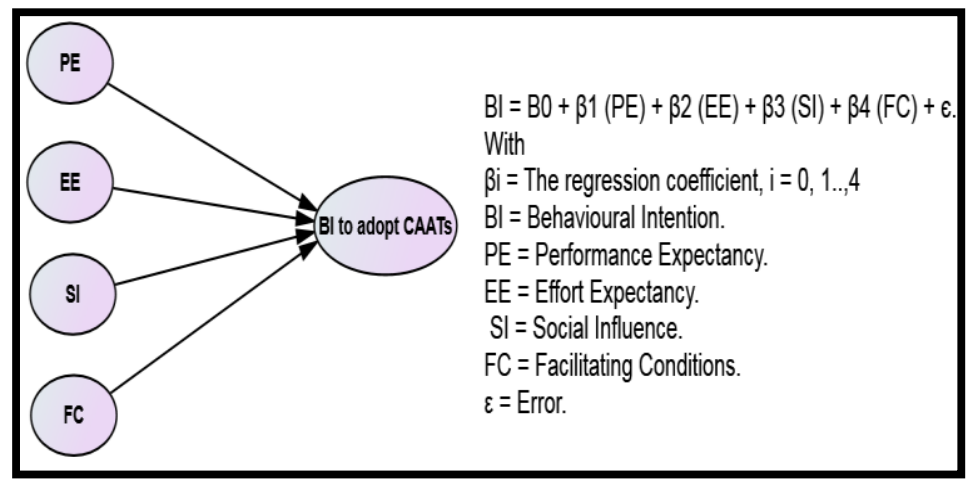

Figure 2. Model of study

\section{Methodology and Data Collection}

A quantitative approach was applied in this study, which is the most appropriate way to validate the conceptual research model. The SEM was applied to test hypotheses, which encompasses a system to study the causal relationships between the latent variables. In the literature, SEM is sufficient to validate measurement and structural causal models (Pedrosa et al., 2019). This study focused on the chartered accountants in Yemen. In this study, a five-point Likert Scale was used, ranging from: (1) strongly disagree, (2) disagree, (3) undecided, (4) agree and (5) strongly agree. The questionnaire was developed from the literature review (Venkatesh et al., 2003; Bierstaker et al., 2014; Mansour, 2016). The questionnaire consists of two parts. The first part includes information on the demographic characteristics of respondents. The second part includes the 19 questions that related to the constructs of UTAUT. The main constructs of UTAUT include the Performance Expectancy (PE), Effort Expectancy (EE), Social Influence (SI), Facilitating Conditions (FC), and Behavioral Intention (BI).

The survey was conducted in Yemen, and it was distributed electronically and manually to external auditors in Yemen, A detailed inspection of questionnaire, 347 questionnaires were retrieved from external auditors. The responses rate were (69\%), 35 responses did not valid to 




International Journal of Accounting and Financial Reporting

ISSN 2162-3082

analysis, and 312 were valid responses for analysis at a rate (62\%). Table 1 below shows the demographics characteristics of the sample.

Table 1. Demographics characterization of sample

Respondents ( $\mathrm{N}=312)$

\begin{tabular}{|c|c|c|c|}
\hline Characteristics & Contents & Frequency & Percent $\%$ \\
\hline \multirow[t]{3}{*}{ Gender } & Male & 306 & 98 \\
\hline & Female & 6 & 2 \\
\hline & Bachelor degree & 218 & 70 \\
\hline \multirow[t]{3}{*}{ Education } & Master degree & 79 & 25 \\
\hline & $\mathrm{PhD}$ & 15 & 5 \\
\hline & Novice & 78 & 25 \\
\hline \multirow[t]{4}{*}{ IT expertise } & Intermediate & 165 & 53 \\
\hline & Expert & 69 & 22 \\
\hline & Less than 27 years & 5 & 2 \\
\hline & $27-35$ years & 53 & 17 \\
\hline \multirow{2}{*}{ Age } & More than 35 and less than 45 years & 208 & 67 \\
\hline & More than 45 years & 46 & 15 \\
\hline
\end{tabular}

The measure of variables of study as shown in Table 2 Appendix A. Table 2 shows questions of constructs of UTAUT, which were used the measure of variables of the study. Following (Ebimobowei et al., 2013; Mansour, 2016; Mohammad et al., 2017; Zainol et al., 2017) external auditors were asked to assess the factors that affect CAATs adoption and usage decisions on a five-point Likert Scale ranging from 1 ('strongly disagree') to 5 ('strongly agree'). Table 3 shows the constructs of the model and its definitions. 
Table 3. Constructs of the model

Constructs Definition of constructs

Performance "degree to which an individual believes that using the system will help expectancy him or her to attain gains in job performance” (Venkatesh et al., 2003)

$\begin{array}{ll}\text { Effort } & \text { "degree of ease associated with use of the system" (Venkatesh et al., } \\ \text { expectancy } & 2003 \text { ) }\end{array}$

Social influence

"degree to which an individual perceives that important others believe he or she should use the new system" (Venkatesh et al., 2003)
Facilitating
conditions
"degree to which an individual believes that an organizational and technical infrastructure exists to support use of the system" (Venkatesh et al., 2003)
Behavioural "Intention of the individual to perform the behavior". (Venkatesh et al., Intention 2003)

\section{Results}

\subsection{Descriptive Statistics}

As shown in Table 1, 98\% of the respondents were male, and $2 \%$ were female. Relates to the age of participants, it was noticed that the age group of 35-45 captured the largest part of the total sample (69\%). The descriptive statistics also showed that the most prominent educational level of respondents was the Bachelor's Degree. In relation to IT expertise, it was noted that a large proportion of respondents $(53 \%)$ were found to have an intermediate level of IT expertise.

The mean predictor variables are shown in Table 4 , the mean ratings of respondents to the performance expectancy was (4.27), effort expectancy was (3.85), social influence was (3.80), facilitating conditions was (3.88), and behavioral intention was (4.11).

Table 4. Predictor variable means.

\begin{tabular}{llll}
\hline Predictor variable & Mean & Std. dev & Cronbach's coefficient alpha \\
\hline PE1 & 4.31 & .54 & .79 \\
\hline PE2 & 4.29 & .55 & .79 \\
\hline PE3 & 4.27 & .60 & .80 \\
\hline
\end{tabular}




\begin{tabular}{llll}
\hline PE4 & 4.21 & .50 & .84 \\
\hline Average performance expectancy & $\mathbf{4 . 2 7}$ & .85 \\
\hline EE1 & 3.93 & .64 & .76 \\
\hline EE2 & 3.86 & .59 & .65 \\
\hline EE3 & 3.78 & .59 & .64 \\
\hline EE4 & 3.82 & .58 & .67 \\
\hline Average effort expectancy & $\mathbf{3 . 8 5}$ & .87 \\
\hline SI1 & 3.79 & .83 & .84 \\
\hline SI2 & 3.79 & .87 & .81 \\
\hline SI3 & 3.76 & .85 & .82 \\
\hline SI4 & 3.86 & .83 & .84 \\
\hline Average social influence & $\mathbf{3 . 8 0}$ & &. $\mathbf{8 7}$ \\
\hline FC1 & 3.86 & .67 & .75 \\
\hline FC2 & 3.90 & .66 & .66 \\
\hline FC3 & 3.87 & .74 & .78 \\
\hline Average facilitating conditions & $\mathbf{3 . 8 8}$ & .87 \\
\hline BI1 & 4.01 & .74 & .89 \\
\hline BI2 & 4.07 & .86 & .87 \\
\hline BI3 & 4.09 & .86 & .88 \\
\hline AI4 & 4.16 & .82 & .88 \\
\hline $\mathbf{4 . 1 1}$ & $\mathbf{. 9 1}$ \\
\hline
\end{tabular}

* Cronbach coefficient alpha with deleted variables of outputs SPSS.

As shown in Table 4, scale reliability was determined based on Cronbach's alpha. Cronbach's alpha coefficient should be over the threshold of 0.70 for acceptability (Nunnally, 1978). The results indicated that the scale reliabilities were high for all latent constructs, were realized as 


\section{MInstitute Macrothink $_{\text {Ins }}$}

International Journal of Accounting and Financial Reporting

ISSN 2162-3082

2020, Vol. 10, No. 2

following: performance expectancy (0.85), effort expectancy (0.74), social influence (0.87), facilitating conditions ( 0.80$)$, and behavioral intention (0.91).

\subsection{Normality}

Table 5 demonstrates the normal distribution test for data. The statistical values of skewness and kurtosis were adopted to the normal distribution test of data. The statistical values of skewness and kurtosis have been tested using SPSS $\mathrm{v}_{20.0}$, and found to be within their respective ranges $(+2,-2)$ (George \& Mallery, 2010). Therefore, the findings indicate the data follow the normality.

Table 5. Normality

\begin{tabular}{|c|c|c|c|}
\hline Constructs & Items & Skewness & Kurtosis \\
\hline \multirow[t]{4}{*}{ Performance Expectancy } & PE1 & -.301 & 1.612 \\
\hline & PE2 & -.212 & .823 \\
\hline & PE3 & -.447 & .878 \\
\hline & PE4 & -.185 & .888 \\
\hline \multirow[t]{4}{*}{ Effort Expectancy } & EE1 & -.594 & 1.207 \\
\hline & EE2 & -.452 & .980 \\
\hline & EE3 & -.457 & .656 \\
\hline & EE4 & -.461 & .838 \\
\hline \multirow[t]{4}{*}{ Social Influences } & SI1 & -.671 & .418 \\
\hline & SI2 & -.509 & -.002 \\
\hline & SI3 & -.618 & .087 \\
\hline & SI4 & -.793 & .662 \\
\hline \multirow[t]{3}{*}{ Facilitating Conditions } & FC1 & -.419 & .507 \\
\hline & FC2 & -.478 & .696 \\
\hline & FC3 & -.517 & .330 \\
\hline \multirow[t]{4}{*}{ Behavioural Intention } & BI1 & -.766 & .785 \\
\hline & $\mathrm{BI} 2$ & -.719 & -.040 \\
\hline & $\mathrm{BI} 3$ & -.836 & .211 \\
\hline & $\mathrm{BI} 4$ & -1.026 & 1.291 \\
\hline
\end{tabular}




\subsection{Validation of the Measurement Scales}

We have two steps in the factors analysis. The first step, the exploratory factor analysis (EFA) to identify the strength of factor loading. Table 6 shows the factor loading for each latent construct, which should exceed 0.50 for all items. Second, scale reliability was determined based on Cronbach's alpha. Table 4 shows the results of Cronbach's alpha reliability coefficients, which should exceed the threshold (0.70) (Nunnally, 1978). Results indicate that all constructs are higher than the threshold (0.70). The statistical results indicated that the scale reliability of the performance expectancy was (0.85), effort expectancy (0.74), social influence (0.87), facilitating conditions (0.80), and behavioral intention (0.91).

Table 6. Factor loadings (bolded) and cross loadings

\begin{tabular}{|c|c|c|c|c|c|}
\hline & $\mathrm{PE}$ & $\mathrm{EE}$ & SI & $\mathrm{FC}$ & BI \\
\hline PE1 & .820 & .169 & .208 & .172 & .280 \\
\hline PE2 & .822 & .180 & .182 & .115 & .306 \\
\hline PE3 & .820 & .120 & .180 & .166 & .258 \\
\hline PE4 & .785 & .178 & .162 & .066 & .130 \\
\hline EE1 & .247 & .567 & .273 & .185 & .200 \\
\hline EE2 & .116 & .796 & .231 & .130 & .187 \\
\hline EE3 & .090 & .811 & .281 & .168 & .239 \\
\hline EE4 & .117 & .735 & .335 & .213 & .228 \\
\hline SI1 & .134 & .324 & .791 & .278 & .362 \\
\hline SI2 & .217 & .352 & .793 & .371 & .432 \\
\hline SI3 & .180 & .288 & .829 & .262 & .340 \\
\hline SI4 & .215 & .294 & .787 & .276 & .379 \\
\hline FC1 & .139 & .236 & .342 & .791 & .373 \\
\hline $\mathrm{FC} 2$ & .113 & .185 & .266 & .858 & .406 \\
\hline FC3 & .151 & .171 & .288 & .772 & .380 \\
\hline BI1 & .228 & .260 & .431 & .456 & .783 \\
\hline BI2 & .251 & .229 & .383 & .380 & .863 \\
\hline BI3 & .276 & .240 & .378 & .395 & .846 \\
\hline
\end{tabular}




$\begin{array}{llllll}\text { BI4 } & .294 & .279 & .400 & .389 & \mathbf{. 8 1 8}\end{array}$

Extraction Method: Principal Component Analysis

$\begin{array}{lccccc}\text { Eigenvalues } & 1.98 & 1.534 & 2.37 & 1.36 & 6.05 \\ \text { Percent-explained } & 10.44 & 8.07 & 12.45 & 7.16 & 31.84\end{array}$

\subsection{Structural Equation Modeling Analysis}

The SEM was selected as a statistical approach in this study. Using Amos 23.0 to analyze the empirical data of the study. The two-stage SEM statistical approach was employed. The first stage, evaluating the measurement model. The second stage, estimating the structural model to test study hypotheses (Hair et al., 2010). Figur.3 shows the initial measurement model of the study.

\subsubsection{The Measurement Model: Confirmatory Factor Analysis (CFA)}

The measurement model: CFA is shown in Figure 3 as bellow:

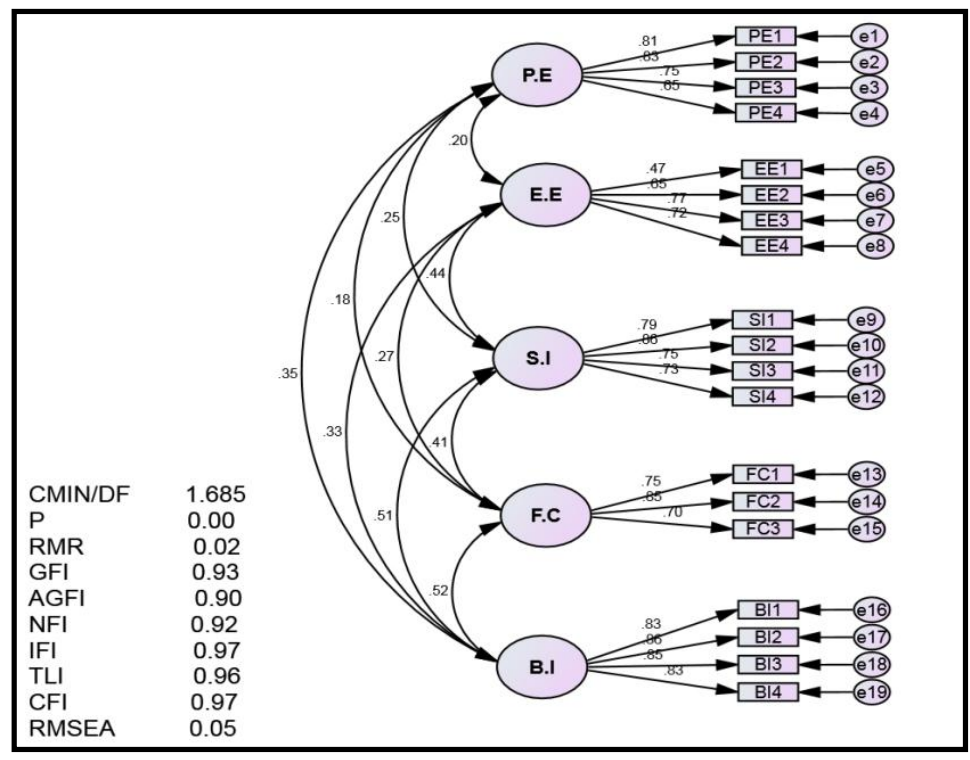

Figure 3. Initial measurement model: CFA

Table 7. Results of initial measurement model

\begin{tabular}{llllllllll}
\hline Indices & CMIN & P & GFI & AGFI & NFI & IFI & TLI & CFI & RMSEA \\
\hline & & $>.05$ & $\geq 0.90$ & $\geq 0.80$ & $\geq 0.90$ & $\geq 0.90$ & $\geq 0.90$ & $\geq 0.90$ & $\leq 0.08$ \\
\hline Values & 239.222 & .000 & 0.93 & 0.90 & 0.92 & 0.97 & 0.96 & 0.97 & 0.05 \\
\hline
\end{tabular}

We performed a CFA using Amos $v_{23}$ as shown in Table 7. The following statistical fitness indices. The chi-square value is close to zero, the probability level for the chi-square $<0.5(\mathrm{p}$ $=0.00,142 \mathrm{df})$. Goodness-of-Fit Index $(\mathrm{GFI})=0.93(\geq 0.90)$; Adjusted Goodness-of-Fit 


\section{Mll Macrothink}

International Journal of Accounting and Financial Reporting

ISSN 2162-3082

2020, Vol. 10, No. 2

Index $($ AGFI $)=0.90(\geq 90 \%)$; Normed-Fit Index $(\mathrm{NFI})=0.92(\leq 0.90)$; Incremental Fit Index $(\mathrm{IFI})=0.97(\geq 0.90)$; Tucker-Lewis coefficient (TLI) $=0.96(\geq 0.90)$; Comparative Fit Index $(\mathrm{CFI})=0.97(\geq 0.90)$; and Root Mean Square Error of Approximation (RMSEA) $=$ $0.05(\leq 0.08)$. Thus, the values of indices are acceptable with the criteria of good fitness. However, the loading of the item (EE1) from effort expectancy $=0.47$. It was observed to be under its cut-off value (0.50). We will drop it from this model. The outer loading is below the threshold of 0.50 (Hair et al., 2010). Therefore, there is room for some reassessment and purification to reach the model. By doing so, we did analyze again, the model fitness improved. We found all the indices this time were fitness, (Anderson\& Gerbing, 1988; Byrne, 2010). As shown in Table 8, the model demonstrates good fitness which, the fit indices including CMIN/DF, RMR, AGFI, GFI, NFI, IFI, TLI, CFI and RMSEA that evaluate the model fitness. Figur.4 shows to the modified measurement model of study.

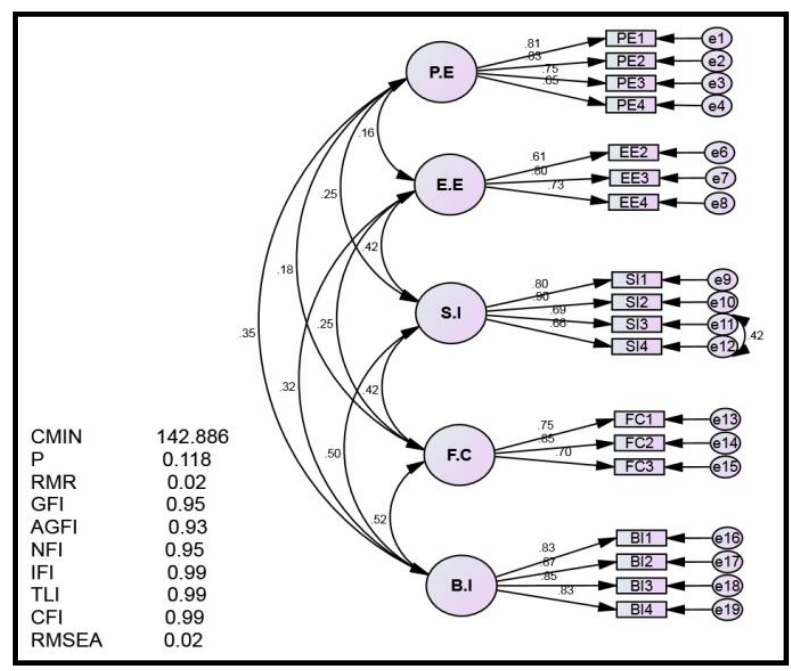

Figure 4. Modified measurement model

Table 8. Result of modified measurement model

\begin{tabular}{llllllllll}
\hline Indices & CMIN & P & GFI & AGFI & NFI & IFI & TLI & CFI & RMSEA \\
\hline & & $>.05$ & $\geq 0.90$ & $\geq 0.90$ & $\geq 0.90$ & $\geq 0.90$ & $\geq 0.90$ & $\geq 0.90$ & $\leq 0.08$ \\
\hline Values & 142.886 & .118 & 0.95 & 0.93 & 0.95 & 0.99 & 0.99 & 0.99 & 0.02 \\
\hline
\end{tabular}

The results of statistical fitness indices for the modified measurement model shows in Table 8 . Indices of measurement model were found as follows: CMIN was $142.886(0.118, \mathrm{P}>0.05)$, GFI $=0.95(\geq 0.90)$, AGFI $=0.93(\geq 90 \%), \mathrm{NFI}=0.95(\leq 0.900), \mathrm{IFI}=0.99(\geq 0.90),(\mathrm{TLI})=$ $0.99(\geq 0.90), \mathrm{CFI}=0.99(\geq 0.90)$ and RMSEA $=0.02(\leq 0.08)$. All factor loadings were greater than the $(0.50)$ acceptability threshold and all are significant $(\mathrm{p}<0.05)$. According to the modified measurement model, all the indices indicated to a good model fitness. 


\section{Mll Macrothink}

International Journal of Accounting and Financial Reporting

ISSN 2162-3082

2020, Vol. 10, No. 2

\subsubsection{Construct Validity}

Table 9 demonstrates convergent validity. The scale validity construct was tested through the Composite Reliability (CR) and Average Variance Extracted (AVE). The latent constructs have the CR ranged from 0.76 to 0.91 . Moreover, the cut-off point of AVE is 0.50 (Fornell \& Larcker, 1981). According to (Hair et al., 2010) factor loadings are greater than 0.50 . The latent constructs have AVE ranged from 0.52 to 0.85 . In addition, the results of convergent validity demonstrate that all items had a significant standardized regression weight.

Discriminant validity as shown in Table 10. The findings indicated the square root of the AVE for each factor was higher than the square of correlation in comparison with the other factors. Therefore, we can say the latent constructs reached an acceptable level of discriminant validity (Hair et al., 2010).

\subsubsection{Common Method Variance}

To ensure that the data is free from the common method bias, an inspection of Harman's single-factor with five latent constructs (PE, EE, SI, FC, and BI). Using SPSS 20.0, to conduct a test of common method bias, and 19 scale items of the model were conducted (Harman, 1976; Podsakoff et al., 2003). All items were loaded into the EFA and examined by using concept axis factoring. The statistical results indicated that the first factor was accounted for $31.835 \%$, which was less than the threshold of $50 \%$ (Harman, 1976). Thus, the data has not any bias according to the common method variance.

Table 9. Convergent validity

\begin{tabular}{lllll}
\hline $\begin{array}{l}\text { Latent } \\
\text { Construct }\end{array}$ & $\begin{array}{l}\text { Cronbach's } \\
\text { Alpha }(\alpha)\end{array}$ & $\begin{array}{l}\text { Composite } \\
\text { Reliability } \\
(\mathrm{CR})\end{array}$ & $\begin{array}{l}\text { Average } \\
\text { Variance } \\
\text { Extracted } \\
\text { (AVE) }\end{array}$ & $\begin{array}{l}\text { Roots of } \\
\text { Average } \\
\text { Variance } \\
\text { Extracted }\end{array}$ \\
\hline $\mathrm{PE}$ & 0.85 & 0.85 & 0.58 & 0.76 \\
\hline $\mathrm{EE}$ & 0.74 & 0.76 & 0.52 & 0.72 \\
\hline $\mathrm{SI}$ & 0.87 & 0.87 & 0.85 & 0.79 \\
\hline $\mathrm{FC}$ & 0.80 & 0.80 & 0.59 & 0.77 \\
\hline $\mathrm{BI}$ & 0.91 & 0.91 & 0.71 & 0.84 \\
\hline
\end{tabular}




\section{Ml Macrothink}

International Journal of Accounting and Financial Reporting

ISSN 2162-3082 2020, Vol. 10, No. 2

Table 10. Discriminant validity

\begin{tabular}{llllll}
\hline Latent Construct & PE & EE & SI & FC & BI \\
\hline PE & $\mathbf{0 . 7 6}$ & & & & \\
\hline EE & 0.16 & $\mathbf{0 . 7 2}$ & & & \\
\hline SI & 0.25 & 0.42 & $\mathbf{0 . 7 9}$ & & \\
\hline FC & 0.18 & 0.25 & 0.41 & $\mathbf{0 . 7 7}$ & \\
\hline BI & 0.35 & 0.32 & 0.51 & 0.52 & $\mathbf{0 . 8 4}$ \\
\hline
\end{tabular}

*Diagonal values in Table 10 indicate the squared roots of average variance extracted.

*Off-diagonal values in Table 10 indicate the correlation between the latent constructs.

\subsubsection{Structural Model and Hypotheses Testing}

Figure 5 shows the good fitness indices of structural model. By running Amos $v_{23}$ to test the study hypotheses, 5 causal paths were inspected for the structural model.

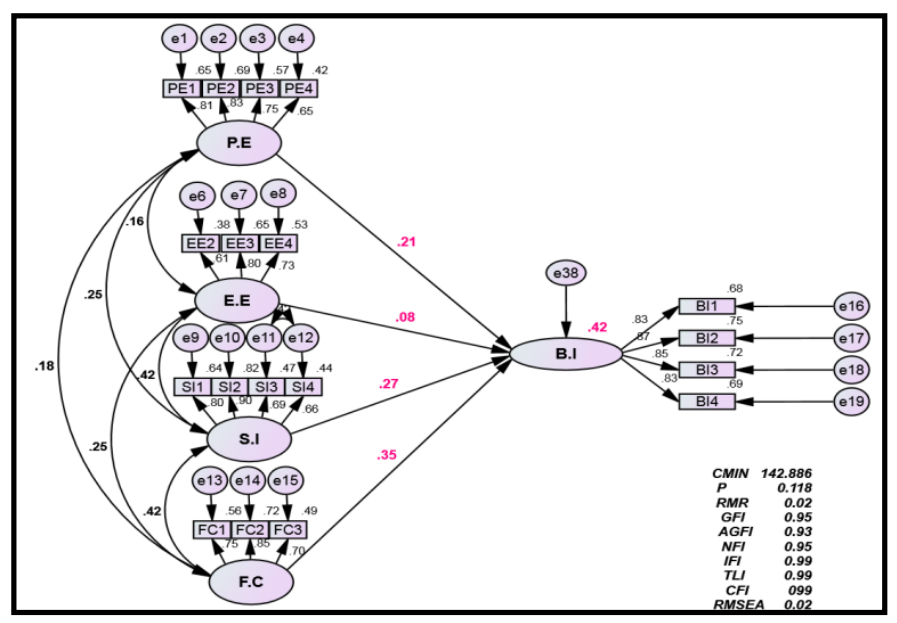

Figure 5. Structural model results

Table 11. Indices of the structural model

\begin{tabular}{llllllllll}
\hline Indices & CMIN & P & GFI & AGFI & NFI & IFI & TLI & CFI & RMSEA \\
\hline & & $>.05$ & $\geq 0.90$ & $\geq 0.90$ & $\geq 0.90$ & $\geq 0.90$ & $\geq 0.90$ & $\geq 0.90$ & $\leq 0.08$ \\
\hline Values & 142.886 & .118 & 0.95 & 0.93 & 0.95 & 0.99 & 0.99 & 0.99 & 0.02 \\
\hline
\end{tabular}




\section{MIMacrothink}

International Journal of Accounting and Financial Reporting

ISSN 2162-3082

2020, Vol. 10, No. 2

The measurement of indices. As shown in Table 11, the fitness indices for the structural model of adoption of CAATs were realized as follows: CMIN was $142.886(0.118, \mathrm{P}>0.05)$, GFI $=0.95(\geq 0.90)$, AGFI $=0.93(\geq 90 \%), \mathrm{NFI}=0.95(\geq 0.900)$; IFI $=0.99(\geq 0.90)$, TLI $=$ $0.99(\geq 0.90)$, CFI $=0.99((\geq 0.90)$, and RMSEA $=0.02(\leq 0.08)$. All the indices of the modified structural model indicate good model fitness. In addition, all loading of items were greater than (0.50) (Hair et al., 2010). Figure 5 displays estimates of the standardized parameters for the structural model and it provide the evidence for the testing of our hypotheses. The following structural equations were derived from the above research model:

$$
\mathrm{BI}=\mathrm{B}_{0}+\beta_{1}(\mathrm{PE})+\beta_{2}(\mathrm{EE})+\beta_{3}(\mathrm{SI})+\beta_{4}(\mathrm{FC})+\epsilon
$$

With

$\beta \mathrm{i}=$ The regression coefficient, $\mathrm{i}=0,1 . ., 4$

$\mathrm{BI}=$ Behavioural Intention .

$\mathrm{PE}=$ Performance Expectancy

$\mathrm{EE}=$ Effort Expectancy

$\mathrm{SI}=$ Social Influence.

$\mathrm{FC}=$ Facilitating Conditions.

$\varepsilon=$ Error.

Table 12 shows the testing of the hypotheses. By running Amos $v_{23}$, the standardized path coefficient from the performance expectancy to the behavioural intention is $(0.21 ; p<0.001)$. Thus the $\mathrm{H} 1$ is confirmed. The standardized path coefficient from the effort expectancy to behavioural intention is $(0.08 ; \mathrm{p}>0.05)$. Therefore, the $\mathrm{H} 2$ is rejected. The standardized path coefficient from the social influence to the behavioural intention is $(0.27 ; p<0.05)$. Therefore, the hypothesis $\mathrm{H} 3$ is confirmed. The standardized path coefficient from the facilitating conditions to behavioural intention is $(0.35 ; \mathrm{p}<0.001)$. Thus, the H4 is confirmed. The R2 was calculated (0.42). Hence, the UTAUT's key constructs were able to predict about $42 \%$ of the variance in behavioural intention.

Table 12. Testing research hypotheses

\begin{tabular}{lllllllll}
\hline Hypotheses & Path & & $\begin{array}{l}\text { Standardized } \\
\text { Estimate }\end{array}$ & C.R (z) & p & $\begin{array}{l}\text { Confirmed/ } \\
\text { rejected }\end{array}$ \\
\hline $\mathrm{H}_{1}$ & BI & $<---$ & PE & 0.21 & 3.651 & $* * *$ & confirmed \\
\hline $\mathrm{H}_{2}$ & BI & $<---$ & EE & 0.08 & 1.246 & 0.213 & rejected \\
\hline $\mathrm{H}_{3}$ & BI & $<---$ & SI & 0.27 & 4.167 & $* * *$ & confirmed \\
\hline $\mathrm{H}_{4}$ & BI & $<---$ & FC & 0.35 & 5.418 & $* * *$ & confirmed \\
\hline
\end{tabular}

Note: $* * * \mathrm{p}<0.001$ 


\section{Discussion of Findings}

The UTAUT model suggests that PE, EE, SI, and FC affect behavioral intention to adopt and use new technology. The structural model theoretical of UTAUT represented the basis in the formulation of the proposed study model, which determines the relationships between variables. The main fit indicators of model were as follows: CMIN was $142.886(0.118, \mathrm{P}>$ 0.05), $\mathrm{GFI}=95, \mathrm{AGFI}=93, \mathrm{NFI}=95, \mathrm{IFI}=99, \mathrm{TLI}=99, \mathrm{CFI}=99$ and RMSEA 0.02. The values of these indicators indicate the strong relationship between the factors of this model. Thus, the modified structural model had sufficient goodness of fit indices. In addition, the modified structural model had an appropriate degree of validity and reliability.

The results of the analysis using the SEM show that behavioural intention was influenced by three factors. The results show that performance expectancy is a significant factor predicting the external auditors' intentions to accept CAATs in the audit process in Yemen. This result is consistent with previous studies such as (Bierstaker et al., 2014; Curtis \& Payne, 2014; Mansour, 2016; Zainol, 2017; Mohammad et al., 2017; Al-Hiyari et al., 2019). In addition, these findings agree with the original UTAUT, which states that there is a positive effect between the performance expectancy and behavioural intention. This means that the Yemeni external auditor perceives a higher level of performance expectancy from adoption of CAATs. Thus, the behavioral intention of the external auditor to use CAATs in audit is expected to be high. This means that the external auditors feel the adoption of CAATs in their work. It will help them to improve their performance, saving costs, complete their works and increased productivity. The external auditor perceives that using CAATs leads to carry out audit effectively. This leads to a positive perception of the external auditor and enhances their behavioral intentions to use CAATs.

Findings also show that effort expectancy is an insignificant factor predicting the external auditors' intentions to accept CAATs. This result is consistent with the prior studies such as (Bierstaker et al., 2014; Mahzan \& Lymer, 2014; Mansour, 2016; Zainol et al., 2017; and Al-Hiyari et al., 2019), but conflicts with the findings of (Venkatesh et al., 2003; Ebimobowei et al., 2013; and Pedrosa et al., 2019), meaning that the external auditors feel that CAATs is not easy to use. In addition, the personal preferences related to effort variable, it may less weight than any individual decision regarding individual technology choice decision (Bierstaker et al., 2014).

Statistical findings indicated that social influence positively influences the external auditors' intentions to accept CAATs. This explains that the social influence of the top management, seniors, peers, and superiors plays an important role in influence CAATs adoption. They have the highest authority to decide on CAATs adoption (Zainol, 2017). This result is consistent with previous studies such as (Venkatesh et al., 2003; Ebimobowei et al., 2013; Mohammad et al., 2017; Zainol, 2017) but, conflicts with findings of (Bierstaker et al., 2014; Mahzan \& Lymer, 2014; Mansour, 2016; Al-Hiyari et al.,2019; Pedrosa et al., 2019). The prior studies show that social influence is a vital factor to adopt and use new technology (Ahmad et al., 2013). This implies that the Yemeni external auditors perceive that social influence is a significant factor in implementing CAATs. Finally, the empirical findings have supported that 


\section{Mll Macrothink}

International Journal of Accounting and Financial Reporting

ISSN 2162-3082

2020, Vol. 10, No. 2

facilitating conditions a positive impact on the external auditors' intentions to adopt CAATs. This finding is consistent with the prior studies of (Mansour, 2016; Zainol et al., 2017; Al-Hiyari et al., 2019; Pedrosa et al., 2019), but contradicts with the result of (Mohammad et al., 2017). This finding indicates that audit firms should be spending enough money in the infrastructure and technical resources that related technology to adopt and use CAATs.

\section{Conclusion}

The main objective of this study was to examine the factors that influence the CAATs adoption in the external audit process in Yemen. The conceptual model of our study was based on the constructs of UTAUT, which was formulated by (Venkatesh et al., 2003).

A quantitative approach was carried out by a questionnaire. After surveying 312 external auditors, this study found three important factors from UTAUT that may affect external auditors' intentions to adopt CAATs. These factors were the facilitating conditions, social influence, and performance expectancy, but the effort expectancy was insignificant.

\section{Contribution}

From a practical perspective, these findings support the important role of constructs of the UTAUT. Hence, the aspects relating to these constructs must be the focus of the attention of any audit firm in Yemen to adopt CAATs. Furthermore, this is the first study in Yemen about factors that influence CAATs adoption. Besides, this study will contribute to future researches as a reference.

\section{Theoretical Implications}

The study recommends that audit firms should support the CAATs implementation, to ensure adequate resources and comprehensive training for auditors. Moreover, support awareness knowledge, encourage and ongoing training that relates to CAATs adoption.

\section{Limitations}

The data of the current study were obtained by questionnaire. This study is a cross-sectional study, which utilized a one -year data. Which in turn, may be reflected negatively on the quality of results. In addition, the statistic descriptive of the sample showed that the largest part of the participants in our study was above 35 years. Moreover, this raises concerns regarding the applicability of the results of the study for other samples different in an age such as young's age.

\section{Future Research}

Future research can be extended this study through other proposed factors, using qualitative evidence to improve the quantitative approach in the real context.

\section{References}

Ahmad, M. O., Markkula, J., \& Oivo, M. (2013). Factors affecting e-government adoption in Pakistan: a citizen's perspective. Transforming Government: People, Process and Policy, 7(2), 225-239. 


\section{$\triangle$ Macrothink}

International Journal of Accounting and Financial Reporting

ISSN 2162-3082

Al-Hiyari, A., Al Said, N., \& Hattab, E. (2019). Factors That Influence the Use of Computer Assisted Audit Techniques (CAATs) By Internal Auditors in Jordan. Academy of Accounting and Financial Studies Journal, 23(3), 1-15.

American Institute of Certified Public Accountants (AICPA). (2001). 'The effect of information technology on the auditor's consideration of internal control in a financial statement audit. Statement of Auditing Standards No. 94. New York, NY.

American Institute of Certified Public Accountants (AICPA). (2002). Consideration of fraud in a financial statement audit. Statement of Auditing Standards No. 99. New York, NY: AICPA.

American Institute of Certified Public Accountants (AICPA). (2002b). Interim financial information. Statement of auditing standard No. 100. New York, NY: AICPA.

American Institute of Certified Public Accountants (AICPA). (2002C). Audit documentation. Statement of Auditing Standard No. 96. New York, NY: AICPA.

American Institute of Certified Public Accountants (AICPA). (2006). Audit Risk Exposure Standards. Statements of Auditing Standards. New York NY: AICPA.

American Institute of Certified Public Accountants (AICPA). (2015). Evolution of auditing: from the traditional approach to the future audit. Retrieved from https://www.aicpa.org/interestareas/frc/assuranceadvisoryservices/downloadabledocuments/a uditanalytics_lookingtowardfuture.pdf\#page=96

Anderson, J. C., \& Gerbing, D. W. (1988). Structural equation modeling in practice: A review and recommended two-step approach. Psychological Bulletin, 103(3), 411-423.

Bierstaker, J., Janvrin, D., \& Lowe, J. D. (2014). What factors influence auditors' use of computer-assisted audit techniques?. Advances in Accounting, 30(1), 67-74.

Braun, R. L., \& Davis, H. E. (2003). Computer-assisted audit tools and techniques: analysis and perspectives. Managerial Auditing Journal, 18(9), 725-731.

Byrne, B. M. (2010). Structural equation modeling with Amos: Basic concepts, applications and programming (2th ed.). New York: USA: Taylor \& Francis Group.

Byrnes, P. E., Al-Awadhi, A., Gullvist, B., Brown-LLiburd, H., Teeter, R., Warren, J. D. Jr., \& Vasarhelyi, M. (2015). Evolution of auditing: From the traditional approach to the future audit. Continuous Auditing: Theory and Application, 285-297.

Curtis, M. B., \& Payne, E. A. (2014). Modeling voluntary CAAT utilization decisions in auditing. Managerial Auditing Journal, 29(4), 304-326.

Davis, F. D. (1989). Perceived usefulness, perceived ease of use, and user acceptance of information technology. MIS Quarterly, 13, 319-339.

Debreceny, R., Lee, S. L., Neo, W., \& Toh, J. (2005). Employing generalized audit software in the financial services sector: Challenges and opportunities. Managerial Auditing Journal, 
20(6), 605-618.

Ebimobowei, A., Ogbonna, G. N., \& Enebraye, Z. P. (2012). Auditor's Usage of Computer Assisted Audit Tools and Techniques: Empirical Evidence from Nigeria. Research Journal of Applied Sciences, Engineering and Technology, 6(2), 187-195.

Fornell, C., \& Larcker, D. F. (1981). Evaluating structural equation models with unobservable variables and measurement error. Journal of Marketing Research, 18(1), 39-50.

George, D., \& Mallery, M. (2010). SPSS for Windows Step by Step: A Simple Guide and Reference, 17.0 update (10th ed.). Boston: Pearson.

Gonzalez, G. C., Sharma, P. N., \& Galletta, D. F. (2012). The antecedents of the use of continuous auditing in the internal auditing context. International Journal of Accounting Information Systems, 13(3), 248-262.

Hair, J. F., Black, W. C., Babin, B. J., \& Anderson, R. E. (2010). Multivariate Data Analysis: A global Perspective. Pearson. Upper Saddle River: NJ: Pearson Education.

Harman, H. H. (1976). Modern Factor Analysis (3rd ed.). Chicago: University of Chicago press.

International Federation of Accountants (IFAC). (2009). International Education Practice Statement 2: Information Technology for Professional Accountants. Retrieved from https://www.iaesb.org/system/files/meetings/files/3108.pdf

Janvrin, D., Lowe, D. J., \& Bierstaker, J. (2008). Auditor acceptance of computer-assisted audit techniques. Iowa State University, Arizona State University and Villanova University, 4, $1-19$.

Kim, H. J., Kotb, A., \& Eldaly, M. K. (2016). The use of generalized audit software by Egyptian external auditors: the effect of audit software features. Journal of Applied Accounting Research, 17(4), 456-478.

Lin, C. W., \& Wang, C. H. (2011). A selection model for auditing software. Industrial Management \& Data Systems, 111(5), 776-790.

Mahzan, N., \& Lymer, A. (2014). Examining the adoption of computer-assisted audit tools and techniques: Cases of generalized audit software use by internal auditors. Managerial Auditing Journal, 29(4), 327-349.

Mansour, E. M. (2016). Factors Affecting the Adoption of Computer Assisted Audit Techniques in Audit Process: Findings from Jordan. Business and Economic Research, 6(1), 248-271.

Mohammed, A. A., Kamil, S. B., \& Noor, I. B. (2017). Factors influencing adoption of computer assisted audit techniques (CAATs) by external auditors in Jordan. International Journal OF Engineering Sciences \& Management Research, 4(2), 23-27.

Mustapha, M., \& Lai, S. J. (2017). Information Technology in Audit Processes: An Empirical 
Evidence from Malaysian Audit Firms. International Review of Management and Marketing, 7(2), 53-59.

Nunnally, J. C. (1978). Psychometric theory. Educational Researcher, 4(10), 7-21.

Pedrosa, I., Costa, C. J., \& Aparicio, M. (2019). Determinants adoption of computer-assisted auditing tools (CAATs). Cognition, Technology \& Work, 1-19.

Pedrosa, I., Costa, C. J., \& Laureano, R. M. (2015). Motivations and limitations on the use of information technology on statutory auditors' work: An exploratory study. In 2015 10th Iberian Conference on Information Systems and Technologies (CISTI) (pp. 1-6).

Podsakoff, P. M., MacKenzie, S. B., Lee, J. Y., \& Podsakoff, N. P. (2003). Common method biases in behavioral research:A critical review of the literature and recommended remedies. Journal of Applied Psychology, 88(5), 879-903.

Public Company Accounting Oversight Board (PCAOB). (2007). An audit ofinternal control over financial reporting that is integrated with an audit offinancial statements. Auditing Standard No. 5. Washington D.C: PCAOB.

Public Company Accounting Oversight Board (PCAOB). (2010a). The auditor's response to the risks ofmaterial misstatement. Auditing Standard No. 13. Washington D.C: PCAOB.

Rosli, K., Yeow, P. H., \& Siew, E. G. (2012). Computer-assisted auditing tools acceptance using I-Toe: a new paradigm. Pacific Asia Conference on Information Systems (PACIS) (pp. 7-15).

Shamsuddin, A., Logenthiran, A., Rajasharen, L., Dhinesh, A., Maran, L., Ameer, M. F., \& Muthu, L. M. (2015). Factors Influencing Usage Level of Computer Assisted Audit Techniques (CAATs) by Internal Auditors in Malaysia. In Kuala Lumpur International Business, Economics and Law Conference 6 (Vol.1, pp. 123-131).

Sin Tan, K., Chong, S. C., \& Lin, B. (2013). Intention to use internet marketing: A comparative study between Malaysians and South Koreans. Kybernetes, 42(6), 888-905.

Tumi, A. (2013). An investigative study into the perceived factors precluding auditors from using CAATs and CA. International Journal of Advanced Research in Business, 1(3), 1-45.

Vasile-Daniel, C. (2010). How financial auditors use CAATS and perceive ERP systems. Economic Science Series, 19(1), 490-495.

Venkatesh, V., \& Davis, F. D. (2000). A theoretical extension of the technology acceptance model: Four longitudinal field studies. Management Science, 46(2), 186-204.

Venkatesh, V., Morris, M. G., Davis, G. B., \& Davi, F. D. (2003). User acceptance of information technology: Toward a unified view. MIS Quarterly, 27(3), 425-478.

Wu, T. H. (2015). The Relationships between Computer Auditing Activity and Performance. 2015 International Workshop on Computer Auditing Education (pp. 1-7).

Zainol, S. S., Samsuri, A. S., \& Tunku Arifin, T. R. (2017). Determinants of Computer 


\section{Ml Macrothink}

International Journal of Accounting and Financial Reporting

ISSN 2162-3082 2020, Vol. 10, No. 2

Assisted Audit Techniques (CAATs) Adoption. A Study in Small and Medium Practices in Malaysia. European Journal of Business and Social Sciences, 6(2), 135-150.

\section{Appendix}

Appendix A. Table 2

\begin{tabular}{|c|c|c|c|}
\hline Constructs & Items & & Sources \\
\hline \multirow{4}{*}{$\begin{array}{l}\text { Performance } \\
\text { Expectancy }\end{array}$} & PE1 & $\begin{array}{l}\text { I find computer assisted audit techniques (CAATs) } \\
\text { useful in my job }\end{array}$ & Venkatesh et al., (2003) \\
\hline & PE2 & Using CAATs enables me to accomplish tasks & Venkatesh et al., (2003) \\
\hline & PE3 & Using CAATs increases my productivity & Venkatesh et al., (2003) \\
\hline & PE4 & If I use CAATs, I will increase my chances of & Venkatesh et al., (2003) \\
\hline \multirow{4}{*}{$\begin{array}{c}\text { Effort } \\
\text { Expectancy }\end{array}$} & EE1 & My interaction with CAATs is clear and & Venkatesh et al., (2003) \\
\hline & $\mathrm{EE} 2$ & $\begin{array}{l}\text { Getting the skills to use computer assisted audit } \\
\text { techniques is easy for me }\end{array}$ & Venkatesh et al., (2003) \\
\hline & EE3 & $\begin{array}{l}\text { It is easy for me to use tools computer assisted } \\
\text { audit techniques. }\end{array}$ & Venkatesh et al., (2003) \\
\hline & EE4 & Learning how to operate CAATs is an easy process & Venkatesh et al., (2003) \\
\hline \multirow{4}{*}{$\begin{array}{c}\text { Social } \\
\text { Influence }\end{array}$} & SI1 & $\begin{array}{l}\text { Individuals who influence my behavior think that I } \\
\text { should use CAATs. }\end{array}$ & Venkatesh et al., (2003) \\
\hline & SI2 & $\begin{array}{l}\text { Individuals who are significant to me believe that I } \\
\text { should use CAATs. }\end{array}$ & Venkatesh et al., (2003) \\
\hline & SI3 & $\begin{array}{l}\text { My firm senior managers have been cooperative in } \\
\text { the use of CAATs. }\end{array}$ & Venkatesh et al., (2003) \\
\hline & SI4 & In general. our firm has supported the use of & Venkatesh et al.. (2003) \\
\hline \multirow{3}{*}{$\begin{array}{l}\text { Facilitating } \\
\text { Conditions }\end{array}$} & FC1 & The resources necessary to use CAATs are & Venkatesh et al., (2003) \\
\hline & $\mathrm{FC} 2$ & I have the knowledge necessary to use CAATs & Venkatesh et al., (2003) \\
\hline & $\mathrm{FC} 3$ & $\begin{array}{l}\text { Assistance is available for me with CAATs } \\
\text { difficulties by specific person (or group) }\end{array}$ & Venkatesh et al., (2003) \\
\hline \multirow{4}{*}{$\begin{array}{l}\text { Behavioural } \\
\text { Intention }\end{array}$} & BI1 & I intend to use CAATs in the future. & Venkatesh et al., (2003) \\
\hline & BI2 & I forecast I would use CAATs in the coming & Venkatesh et al., (2003) \\
\hline & BI3 & I plan to use CAATs in my work & Venkatesh et al., (2003) \\
\hline & BI4 & $\begin{array}{l}\text { I would like to use computers in future rather than } \\
\text { any other traditional method }\end{array}$ & \\
\hline
\end{tabular}

\section{Copyright Disclaimer}

Copyright for this article is retained by the author(s), with first publication rights granted to the journal.

This is an open-access article distributed under the terms and conditions of the Creative Commons Attribution license (http://creativecommons.org/licenses/by/4.0/) 